\title{
Update on Treatment of Type 1 Diabetes in Childhood
}

\author{
Johnny Ludvigsson
}

Published online: 15 February 2013

(c) Springer Science + Business Media New York 2013

\begin{abstract}
After 90 years of using insulin to treat type 1 diabetes, there has been no radical change in the treatment. Although several discoveries have improved both quality of life and metabolic control, they have not eradicated, morbidity, and mortality. Insulin analogues are sometimes helpful, and pens, pumps, smart glucometers, and educational tools have facilitated and improved treatment. Soon, better insulin pumps and glucose sensors together with sophisticated algorithms and connections leading to closedloop systems will probably further improve and facilitate treatment of many patients with type 1 diabetes. However, the burden for patients will not disappear completely, and modern therapy will still require both competence and motivation of patients. Therefore, the goal should be either to cure the disease via replacement therapy (transplantations) or to stop the destructive process, preserve residual insulin secretion, or even improve insulin secretion via beta-cell regeneration. This will result in a milder disease, a stabler metabolism, simpler treatment, and perhaps even cure. Several studies are ongoing, but nothing has proved useful so far in clinical practice.
\end{abstract}

Keywords Type 1 diabetes - Closed loop $\cdot$ Monoclonal antibodies $\cdot$ GAD $\cdot$ C-peptide $\cdot$ Immune intervention

J. Ludvigsson $(\bowtie)$

Division of Pediatrics, Department of Clinical and Experimental

Medicine, Linköping University, 58185, Linköping, Sweden

e-mail: johnny.ludvigsson@liu.se

\section{Introduction}

Since insulin treatment became available 90 years ago, there has been no radical change in the treatment of type 1 diabetes (T1D). Although a large proportion of children with cancer can be cured, T1D remains chronic and continuously life-threatening. Furthermore, it has become commoner and commoner all over the world, with rapidly increasing incidence not least in recent decades [1]. Intensive treatment with multiple daily injections of insulin, adjusted to regular meals with suitable content, evaluated by regular self-monitoring of blood glucose concentration has decreased the incidence of late vascular complications [2,3] but the risk and fear of hypoglycemia is a serious problem [4] and neither acute nor late complications can be totally avoided, and mortality is still much increased [5•] There is a great need for improvement of treatment. Herein, some trends and efforts are described.

\section{Modern Insulin Preparations}

Children with diabetes are best served if they can receive a supply of basal insulin and also receive a rapidly absorbed insulin before meals. There has been a gradual improvement of insulin preparations. These preparations have made life somewhat easier for children with diabetes, but because diabetes management is so complex, there are few studies suggesting that they actually improve long-term glycemic control. As a human being with no residual insulin secretion should in principal receive human insulin as treatment, the discovery and production of such insulin in the early 1980s could have been regarded as the final goal. Unfortunately, human insulin injected subcutaneously forms hexameric structures and is slowly absorbed into the 
circulation. The development of short-acting structurally modified insulins that are not stored as tight hexamers and are more rapidly released into the blood stream has facilitated treatment of many patients as meal insulins can often be given when the meal starts instead of half an hour or more before the meal. It is possible to give such so-called direct-acting insulin to younger children during or even after the meal when it is difficult to know if a child will eat or not [6]. These insulins include insulin aspart, insulin lispro, and insulin glulisine. Thus, direct-acting insulin has made treatment easier, but hemoglobin $\mathrm{A}_{1 \mathrm{c}}\left(\mathrm{HbA}_{1 \mathrm{c}}\right)$ levels have not been improved, and as these insulin analogues are much more expensive than regular insulin, it is still reasonable that countries and patients with fewer economic resources continue to use human insulins.

Stable basal insulin preparations have made management of diabetes somewhat more logical, but none are perfect. Neutral protamine Hagedorn insulin and the zinccomplexed insulins in the Lente series have variable absorption, and have variable peaks with a risk of hypoglycemia, particularly during the night. In the first world, they have largely been replaced by long-acting insulin analogues. Insulin glargine can often be given only once a day, and leads to less hypoglycemia especially during the night because it has little peak action [7, 8]. Insulin detemir, which may be used similarly, also leads to less nocturnal hypoglycemia. Some studies indicate that insulin determir should have a less variable profile than other basal insulins [9]. The duration of this insulin is only slightly longer than for neutral protamine Hagedorn insulin, which may facilitate a change in dose, e.g., after heavy exercise on a certain day, but often means the disadvantage of two daily injections, one in the morning and one in the evening.

In recent years there has been a negative counterreaction against the long-acting insulin analogues. Even though hypoglycemia during the night seems to be becoming slightly less common [10,11], there are almost no studies showing any clinically significant reduction in $\mathrm{HbA}_{1 \mathrm{c}}$ levels $[12,13]$ and therefore the economic costs may not seem justified. Furthermore, long-acting insulin analogues, especially insulin glargine, have been suspected to increase the risk of cancer [14•,15] because of their increased mitogenic effect and increased binding to the insulin growth factor receptor, which should lead to caution in the very long term treatment of children, even though these suspicions have not been substantiated by careful epidemiological studies.

The development of better insulin is continuing. A very long acting insulin, insulin degludec, has just been approved for use in adults with diabetes [16], and we can expect new products with special properties, hopefully with a more specific effect on the liver, and also with effects related to blood glucose concentration.

\section{Pens and Pumps}

Worldwide, disposable syringes still are very much used, being the cheapest device, but pens have become commoner and commoner. There has been surprisingly little development in this area, and only in recent years did pens with some kind of memory function appear. The Memoir pen from Lilly can be a very useful tool not least for parents who want to obtain information on what doses their child has remembered to take during the day. But unfortunately many teenagers do not use the memory function and therefore the pen does not always decrease the number of omitted doses [17]. There is an even simpler tool, the ECHO pen, to remind patients about when they had their last injection and how many units they received [18]. This pen can be of help for those who have difficulties to remember, e.g., whether the previous meal dose was taken or not, which may be very important. Just missing one insulin dose per week may have a very great influence on the $\mathrm{HbA}_{1 \mathrm{c}}$ level [19•].

There has been a rapid and quite dramatic improvement in insulin pumps. There are now a large number of pumps with advanced systems, and a pump is very helpful for many patients. Treatment of very young children, under 2 years of age, is much easier with a pump than with traditional insulin therapy and therefore an insulin pump is regarded as the treatment of choice in very young patients, if this is economically viable [20]. Beside that indication, pumps are often prescribed on the basis of indications such as:

- Poor or deteriorating metabolic control.

- Labile diabetes, fluctuating blood glucose concentration.

- Severe hypoglycemia, especially at nighttime.

- Difficulties to provide adequate basal insulin (high morning blood glucose concentration).

- Educational/motivational tool (for some time?).

- The patient wants very much to have a pump.

Many studies have shown that pump treatment leads to improvement of quality of life [21], and this together with the possibility to improve $\mathrm{HbA}_{1 \mathrm{c}}$ levels [22•] has led to pumps becoming very common in the treatment of diabetes in children and adolescents in many clinics and countries [23]. But there are also disadvantages with pumps. The risk of ketoacidosis increases, and there are reported cases of very serious complications [24]. Furthermore, the expense does not allow pumps to be used other than in exceptional cases in many areas of the world. Another problem, which is rarely mentioned, is that many pumps, more so than pens, are quite inaccurate in giving the prescribed insulin dose. There can be as much as $20-40 \%$ difference between the given and prescribed number of units, even though this may be overcome as long as the day-to-day variation is 
small. These problems are especially great with the disposable patch pumps.

However, development is continuing. Modern insulin pumps and glucose sensors have made it possible to improve insulin treatment further without increasing the severity of hypoglycemia [25]. The simplest pump approach to reduce the severity of hypoglycemia is to interrupt insulin delivery. An insulin pump with integrated continuous glucose monitoring system (CGM) (Paradigm ${ }^{\circledR}$ Veo; Medtronic) automatically suspends insulin delivery for up to $2 \mathrm{~h}$ when hypoglycemia is detected and the hypoglycemia alarm is not noticed by the patient $[26,27 \cdot]$. Concerns have been raised about the risk of hyperglycemia, especially from false-positive hypoglycemia detection. However, thus far only mild rebound hyperglycemia and minimal ketonemia has been reported after a temporary suspension of insulin infusion.

\section{Glucose Sensors}

The number of insulin injections per se does not seem to have a great influence on the degree of metabolic control [28]. Although self-monitoring of blood glucose concentration is of crucial importance for successful treatment, even 24-h profiles give only glimpses of the real situation. Therefore, a glucose sensor measuring glucose concentration continuously for some days and nights is a radical step forward and should help us to improve treatment and metabolic balance. We have previously reported a positive effect of glucose sensors from a controlled, crossover study in diabetic children and teenagers [29]. However, there are other studies where CGM has led to very limited improvement of $\mathrm{HbA}_{1 \mathrm{c}}$ levels, and no improvement in teenagers [30]. Irrespective of the statistical effects when comparing groups, a certain device or treatment method may be very useful in individual cases. Our experience is that several patients do learn by using the sensor to understand blood glucose concentration in a way they were not able to before. Such insight may have long-lasting positive effects. Before CGM becomes routine, like selfmonitoring of blood glucose concentration is now, glucose sensors can be recommended, e.g.:

- When the $\mathrm{HbA}_{1 \mathrm{c}}$ level is too high or the blood glucose concentration fluctuates in an acceptable way

- When the patient does not accept or understand how to use blood glucose monitoring

- When there are suspicions of hypoglycemia during the night

- When parents and/or patients are afraid of hypoglycemia, especially nocturnal hypoglycemia
- When parents are too worried, leading to very frequent finger pricks

- In situations which need to be elucidated, e.g., how to manage certain situations such as sporting activities and excursions

CGM is still far too expensive, and we need to see competition between companies not only in the quality of the devices but also in lowering the price to make society willing to pay [31]. The instructions on how to use the sensor take time to teach and to learn, and for some patients and parents this seems to be too difficult. The patient has to understand and accept that he/she has make at least enough correct blood glucose concentration determinations each day for calibration of the sensor, otherwise the sensor will stop giving information. Some patients have problems with alarms, and the sensor may also slip out of the skin. Another problem is the lag time between glucose in blood and subcutaneous tissue, a delay that may play some role especially when glucose concentrations are very low. Several patients have subcutaneous glucose concentration lower than the detection limit of the sensor, sometimes for hours without symptoms. The reason for this is not quite clear, but one explanation for this finding may be that subcutaneous glucose concentration may become/remain lower than glucose concentration in blood on its way to the brain.

On the whole, most sensor periods work well and otherwise rebellious teenagers and quite unmotivated patients may find CGM interesting and useful. It probably suits the young generation, used to computers and modern technology. Diabetes teams and physicians have to adapt to the changing world.

\section{Closed-Loop Insulin Delivery}

Closed-loop insulin delivery (artificial pancreas) is a rather recent medical innovation, and aims to achieve near normal blood glucose concentration without increasing the risk of hypoglycemia [32]. A disposable sensor measures interstitial glucose levels, and the glucose values are fed into a control algorithm controlling delivery of a rapid-acting insulin analogue into the subcutaneous tissue by an insulin pump. The night with no meals, periods of physical activity, etc., should be most easily controlled, and severe hypoglycemia is most threatening during the night. Therefore, research has focused on closed-loop insulin delivery during nighttime, and the technique has made progress and clinical use is coming closer [33]).

However, for a long time in the future there will be a need for patients to learn how to handle these devices, and 
interpret the results, not least during infections, longer exercise, and other more dramatic changes of life.

\section{Drugs Other Than Insulin}

Although insulin substitution is the self-evident life-saving treatment of T1D, there are T1D patients who have substantial insulin resistance as part of their clinical picture. Physical activity is important as well as diet and weight reduction in obese patients. However, sometimes this is not feasible, and treatment with metformin was reported to be useful in one small study [34]. In treatment of type 2 diabetes (T2D) there are a number of modern therapies with very promising results, not least the glucagon-like peptide 1 (GLP-1) drugs. These drugs have the advantage of having their effect mainly when blood glucose concentration is elevated, and therefore they do not cause hypoglycemia. On the other hand, their efficacy requires residual insulin secretion and they will therefore probably only be useful during the first few years of T1D. So far the experience in children and adolescents is meager, but studies are ongoing and may well show indications for such therapies soon.

\section{Dietary Trends}

As long as we have no functioning closed-loop system (artificial pancreas) or no sufficiently efficacious method to improve residual insulin secretion, insulin has to be adapted to the diet. The views on diet have varied a lot, from totally free to very restricted. In the early 1980s, when multiple insulin therapy became commoner and blood glucose monitoring became available, there was a trend towards increasing freedom of diet. Soon it was found out that even with multiple insulin therapy the meal doses have to be adapted to the meal content, and gradually restrictions returned. Carbohydrate counting was believed to increase the patient's freedom to vary meal times and amounts, that is, to increase flexibility. However, not only number of grams of carbohydrates play a role, but also glycemic index, amount of fibers, protein, and fat in the diet, total energy, etc. There are now more and more publications confirming the self-evident fact that carbohydrate counting alone is not the final dietary solution [35, 36, 37•].

\section{Educational Tools}

The degree of metabolic control differs very much between different clinical centers. This cannot be explained by insulin regimens, insulin doses, or use of different devices, but seems to have more to do with the way the diabetes teams work, their policy, attitudes, and approach. Psychosocial support and education, giving motivation and compliance, are still cornerstones in the treatment of diabetes in children and adolescents irrespective of the use of modern devices [38••, 39]. The information and attitude at diagnosis of the disease are crucial, and personal contact and the information from the team are of extraordinary importance. However, in addition to this basis, modern techniques can and should be used. Young people have been brought up with the Internet, computers, smartphones, and applications, and for them a modern technique will be natural The number of applications on smartphones useful for treatment of diabetes is growing rapidly, and may facilitate calculation of the amount of carbohydrates, calculations of insulin doses, etc. Modern insulin pumps also have this capability, and the newer glucose meters are more and more sophisticated. There are many websites, some of high quality [40, 41], whereas others may be more superficial and with questionable advice. It is up to the diabetes teams to be up to date and to discuss with their patients and parents from where they obtain their information, and with whom they discuss diabetes treatment.

\section{Clinical Relevance of Preserved Beta-Cell Function}

Even though treatment has improved and modern devices may make life better, the primary goal remains to preserve the endogenous residual insulin secretion, which at best can result in cure of diabetes or at least can make the disease milder. For the patient it would be extremely relevant if insulin injections were no longer needed, but as long as exogenous insulin is needed it is of less interest for the patient how many units an injection contains. As both quality of life and absence of complications are related to blood glucose balance, the treatment goal should be as normal a blood glucose concentration and $\mathrm{HbA}_{1 \mathrm{c}}$ level as possible. Patients with residual insulin secretion usually have stabler blood glucose concentration and lower $\mathrm{HbA}_{1 \mathrm{c}}$ level, and residual insulin secretion facilitates treatment, decreases the risk of serious hypoglycemia, and also decreases the risk of ketoacidosis [42]. Very modest betacell function, with peak stimulated C-peptide concentration above $0.2 \mathrm{nmol} / \mathrm{L}$, has been reported to reduce the risk of long-term complications [43]. Furthermore, C-peptide per se has been proposed to decrease the risk of complications, and there is increasing evidence that $\mathrm{C}$-peptide is not just a peptide keeping the two insulin chains in a certain structure, but is a hormone with several important effects [44]. There are studies ongoing where C-peptide is part of the treatment, and these studies will show whether C-peptide will become part of the standard treatment of T1D. The 
relevance of saving beta cells and improving their function has become even clearer because of studies suggesting that beta cells may regenerate [45]. If that is the case, an end of the destructive process might even mean cure [46].

\section{Immune Interventions}

Several immune interventions have been performed since our first trial with plasmapheresis [47], but so far with insufficient efficacy and/or with unacceptable adverse effects [48-54]. Rather broad treatments with steroids, cytostatics, high doses of immunoglubulins, and antilymphocyte globulins have shown limited effect, partly because adverse events have required both time and dose restrictions. However, in recent years interventions with monocloncal antibodies, especially against the CD3 receptor [55-57], but also against CD20 [58], have been most promising. Even though phase III trials using antiCD3 failed to reach their primary end points [59•], it was clear that the Protégé study did show efficacy when a reasonably high dose of anti-CD3 was used, especially in patients aged 8-18 years. This was especially true in certain populations (mainly patients in the USA, but also in Europe). One can expect that further studies will be done to learn what doses are efficient but without severe adverse events, and in what patient populations the treatment works best.

\section{Treatment with Heat Shock Protein}

The onset of beta-cell destruction has been found to be associated with the spontaneous development of anti-hsp65 $\mathrm{T}$ lymphocytes, and autoimmune diabetes could not only be induced but also treated by the use of this $65-\mathrm{kDa}$ heat shock protein. A specific peptide, DiaPep277, seems to be the active component and it has been tried with intriguing results.

Studies in humans have shown that subcutaneous administration of DiaPep277 may preserve beta-cell function in adults [60], perhaps through induction of a shift from helper $T$ cell type $1\left(T_{h} 1\right)$ to helper $T$ cell type $\left(T_{h} 2\right)$ cytokines [61]. However, the result could depend on outliers, and the efficacy in adults has not been confirmed in diabetic children and adolescents [62, 63].

In a recent phase III trial no immunological differences could be found between adults treated with DiaPep277 or placebo. However, the treatment with DiaPep277 preserved C-peptide levels after glucagon stimulation, but not after the clinically more relevant mixed-meal tolerance test [64].

\section{Glutamic Acid Decarboxylase Treatment}

During our studies with plasmapheresis as immune intervention in newly diagnosed T1D children more than three decades ago, we discovered a new diabetes-related antigen, with an estimated mass of $64 \mathrm{kDa}$ [65], which later was shown to be glutamic acid decarboxylase (GAD) [66]. In the central nervous system $\gamma$-aminobutyric acid is formed when glutamic acid, or glutamate, is decarboxylated by GAD. It has been suggested that $\gamma$-aminobutyric acid regulates hormone release in the pancreas and/or works as a paracrine signaling molecule of importance for communication between the beta cells and other endocrine cells in the islets. But the specific function of GAD in pancreatic islets is unknown, as is its role in the pathogenesis of diabetes. Neither is it known why GAD is a major autoantigen in autoimmune diabetes.

Autoantibodies against GAD are common in T1D, and there are convincing data from the nonobese diabetic mouse model of T1D that administration of the isoform GAD65 can prevent autoimmune destruction of pancreatic beta cells $[67,68]$. These studies have been followed by studies in humans.

An adjuvant formulation, based on Alhydrogel ${ }^{\circledR}$, was developed to provide a drug product (Diamyd ${ }^{\circledR}$ ) used for evaluation in clinical trials. Alhydrogel ${ }^{\circledR}$ is a product of aluminum hydroxide (alum), which is a conventional adjuvant in vaccines for children. As the autoimmune process causing T1D deviates towards $T_{h} 1$ (or cellular) response to autoantigens, alum is used to overcome this bias and influence the response induced by GAD away from a cellular towards a humoral response in order to minimize the risk of exacerbating cell-mediated beta-cell destruction.

To investigate the safety and efficacy of Diamyd ${ }^{\circledR}$ in T1D, a phase II clinical trial in 70 recently diagnosed T1D children and adolescents was conducted [69]. The treatment was very well tolerated and there were no treatmentrelated adverse events reported even after more than 4 years of follow-up. Regarding efficacy, both treatment groups showed a progressive decrease from the baseline in both fasting and stimulated C-peptide secretion. There was a significant effect of treatment on the change in fasting C-peptide levels seen after 30 months $(p=0.045)$, which was also seen when the change in the C-peptide/plasma glucose ratio was taken into account $(p=0.02)$. Stimulated C-peptide secretion, as measured by the area under the curve (AUC), decreased significantly less in the group treated with GAD-alum than in the placebo group, after both 15 months $(p=0.01)$ and 30 months $(p=0.04)$. The statistically significant effect of treatment on the change in fasting and stimulated C-peptide levels at 30 months remained after adjusting for differences in the duration of 
diabetes, age, gender, and baseline GAD autoantibody levels.

The effect on preservation of C-peptide secretion was still seen after more than 4 years of follow-up [70] in those patients with diabetes for less than 6 months at the time of treatment. There were no treatment-related adverse events.

However, a European phase III trial including 334 patients aged 10-20 years failed [71•]!. The study was powered for a $45 \%$ difference, but the C-peptide AUC was only $16-18 \%$ greater in the actively treated patients than in those treated with placebo $(p=0.10)$, and the difference in fasting C-peptide levels was similar $(p=0.07)$. However, in several prespecified subgroups, the efficacy was rather impressive (around $40 \%$ ), and highly significant.. When the results of the Swedish phase II clinical trial and those of the arm of the phase III trial involving patients who received two doses of GAD-alum are combined, there is a highly significant and rather impressive efficacy measured as both fasting C-peptide level and C-peptide AUC after the mixed-meal tolerance test even after 30 months. An American phase II trial also failed [72]. New studies are ongoing, but so far autoantigen treatment is not part of clinical treatment.

\section{Other Types of Experimental Approach}

Islet transplantation gives hope for a cure, but it is still just experimental even though prognosis has improved [73]. There is lack of organs to transplant, and this will continue unless stem cell research makes further progress. Furthermore, the autoimmune process has to be managed to achieve long-term survival and function of the islet cells, or encapsulation techniques need to be developed to protect the islet cells from the immune system [74].

Stem cells can be used not only to produce insulinproducing cells for transplantation, but also for treatment of damaged islets and immune modulation. Mesenchymal stem cells have been used with interesting results [75].

Autoantigen treatment is being studied with different autoantigens and different ways of administration. Combination therapies may be successful, but further studies are needed. We will have to wait for years before there will be clinical application.

DNA vaccines can be used instead of delivering intact autoantigen proteins. DNA vaccination might lead to production of memory cells, which should then lead to a long-term immune response, but we would rather like hyporesponsiveness to obtain tolerance. It is possible to induce apoptosis of autoreactive lymphocytes. So far DNA vaccines to create tolerance in autoimmune disease have mainly been tried in experimental animals.
In recent years some studies have suggested that beta cells can regenerate. GLP-1 might stimulate beta-cell regeneration. In a clinical trial a GLP-1 agonist in combination with monoclonal antibodies interfering with IL-2 was given to patients with long-standing T1D with some residual insulin secretion. The aim was to study whether such treatment could improve C-peptide levels, but the result was negative [76]. Another substance, islet neogenesis associated protein (INGAP), is supposed to have pancreatic regenerative capacity. Administration of INGAP in animals has caused increased beta-cell mass and reversal of hyperglycemia, and INGAP may have regenerating potential in humans. Daily introduction of INGAP or placebo has been tried in a double-blind randomized trial in both T1D and T2D diabetic patients [77]. A per-protocol analysis showed increased arginine-stimulated C-peptide levels during the treatment period, but the effect was lost as soon as 30 days after the end of treatment.

Experimental evidence indicates that vitamin D may play a role in the defense against T1D as well as T2D. Epidemiological data suggest that there is a link between vitamin D deficiency and an increased incidence of T1D. A multinational case-control study and a birth cohort followup study from Finland [78] have both concluded that vitamin $\mathrm{D}_{3}$ supplementation at birth protects against T1D later in life, and a meta-analysis supports similar conclusions [79]. Other studies report lower serum levels of 1 $\alpha, 25$-dihydroxyvitamin $\mathrm{D}_{3}$ (calcitriol) in patients with recently diagnosed $\mathrm{T} 1 \mathrm{D}$ than in healthy control subjects. The protective effects of vitamin D are mediated through the regulation of several components, such as the immune system and calcium homeostasis. Mechanistic studies have shown that 1 $\alpha, 25$-dihydroxyvitamin $\mathrm{D}_{3}$ modulates dendritic cell maturation in vitro and in vivo and facilitates a shift from a $T_{h} 1$ to a $T_{h} 2$ immune response. An increasing amount of evidence suggests that vitamin $\mathrm{D}$ also affects beta cells directly, thereby rendering them more resistant to cellular stress. There are results indicating that vitamin D may also improve insulin sensitivity, which in turn decreases beta-cell stress.

With this background, vitamin $\mathrm{D}$ has been used in patients with recent-onset T1D in an effort to preserve residual insulin secretion. However, so far vitamin D alone has not been efficacious $[80,81]$. It seems reasonable to try vitamin $\mathrm{D}$, both in a higher dose, and in combination with other therapy, and such studies are ongoing.

Although T1D is regarded as an autoimmune disease, there are several studies both in experimental animals and in humans suggesting that an existing inflammation plays an important role in how the immune system will respond when autoantigens are presented to T cells. IL- 1 has been proposed to be a major player in the destruction of the insulin-producing beta cells [82], and blocking IL-1 in 
experimental animals has shown important effects on the disease process. Use of IL-1 inhibitor in T1D has been shown to reduce serum IL- 8 levels and to reduce CD11b integrin expression on monocytes associated with increased CXCR1 expression. These effects suggest that blockade of the IL-1 $\beta$ pathway results in a reduced ability of mononuclear cells to go to sites of inflammation. However, two separate trials blocking the effect of IL-1 in T1D have recently failed (not yet published). The use of IL-1 receptor antagonist showed no effect on preservation of C-peptide secretion or any related clinical parameter, and the same was the case in another phase II trial using an IL-1 antagonist, anakinra. Furthermore blocking IL-1 caused negative adverse events. Thus, as single therapy antiinflammatory drugs seem insufficient, but might still be of interest in combination with other therapies.

\section{Future Perspectives}

Parallel to the development of new and better insulin and smart devices such as pens, insulin pumps, glucose sensors, and even closed-loop systems, efforts will be made to improve treatment of T1D in children and adolescents in other ways. GLP-1 analogues may become helpful in patients with residual beta-cell function and the use of C-peptide might show efficacy. Trials to save residual beta cells and facilitate regeneration will be important. As no immune intervention so far has been successful, combination therapies have to and will be tried. Autoantigen treatment will probably be part of such combination therapies of manifest T1D. Even though GAD-alum has not shown any stable efficacy so far, and DiaPep277 has only shown slight efficacy in adults, there is still reasonable hope that further studies will tell us how to use autoantigens, probably in combination with other therapies such as vitamin $\mathrm{D}$, monoclonal antibodies, and perhaps antiinflammatory drugs. Treatment of diabetes in children will hopefully and probably be rather different from that at present in the very near future.

Acknowledgments In addition to the author, the Linköping Diabetes Immune Intervention study group consists of Rosaura Casas, Stina Axelsson, Mikael Chéramy, Mikael Pihl, and Linda Åkerman. We are grateful to excellent technical assistance from Ingela Johansson and Gosia Smolinska, and from Eva Isacson and AnnMarie Sandström. All pediatricians involved in our studies are also gratefully acknowledged. Our studies on immune intervention have been generously supported by Barndiabetesfonden (Swedish Child Diabetes Foundation), the Swedish Research Council,and the Research Council of Southeast Sweden (FORSS), and the mechanistic studies are supported by the Juvenile Diabetes Research Foundation (JDFR).

Disclosure Diamyd Medical was a sponsor for the phase II/III GAD trials and has also provided financial support for the investigatorinitiated mechanistic studies connected to these trials. Honoraria for lectures have been received from Novo Nordisk, Lilly, and SanofiAventis. The author has been member of advisory boards of Novo Nordisk, Pfizer and GlaxoSmithKline and is now a member of the advisory board of LifeScan.

\section{References}

Papers of particular interest, published recently, have been highlighted as:

- Of importance

•- Of significant importance

1. Aanstoot HJ, Anderson BJ, Daneman D, Danne T, Donaghue K, Kaufman F, Réa RR, Uchigata Y. The global burden of youth diabetes: perspectives and potential. Pediatr Diabetes. 2007; 8(Suppl 8):1-44.

2. The Diabetes Control and Complications Trial Research Group. The effect of intensive treatment of diabetes on the development and progression of long-term complications in insulin-dependent diabetes mellitus. N Engl J Med. 1993;329:977-86.

3. Bojestig M, Arnqvist HJ, Hermansson G, Karlberg BE, Ludvigsson J. Declining incidence of nephropathy in insulin-dependent diabetes mellitus. N Engl J Med. 1994;330:15-8.

4. Wild D, Von Maltzahn R, Brohan E, Christensen T, Clauson P, Gonder-Frederick L. A critical review of the literature on fear of hypoglycemia in diabetes: implications for diabetes management and patient education. Patient Educ Couns. 2007;68:10-1.

5. - Harjutsalo V, Forsblom C, Groop PH Time trends in mortality in patients with type 1 diabetes: nationwide population based cohort study. BMJ. 2011;343:d5364. This article analyzing a very large amount of patient material in a country with high quality of treatment shows alarming figures for T1D mortality.

6. Danne T, Aman J, Schober E, Deiss D, Jacobsen JL, Friberg HH. Jensen LH; ANA 1200 Study Group A comparison of postprandial and preprandial administration of insulin aspart in children and adolescents with type 1 diabetes. Diabetes Care. 2003;26(8): 2359-64.

7. Chase HP, Arslanian S, White NH, Tamborlane WV. Insulin glargine versus intermediate-acting insulin as the basal component of multiple daily injection regimens for adolescents with type 1 diabetes mellitus. J Pediatr. 2008;153(4):547-53.

8. Monami M, Marchionni N, Mannucci E. Long-acting insulin analogues vs. NPH human insulin in type 1 diabetes. A metaanalysis. Diabetes Obes Metab. 2009;11(4):372-8.

9. Danne T, Datz N, Endahl L, Haahr H, Nestoris C, Westergaard L, Fjording MS, Kordonouri O. Insulin detemir is characterized by a more reproducible pharmacokinetic profile than insulin glargine in children and adolescents with type 1 diabetes: results from a randomized, double-blind, controlled trial. Pediatr Diabetes. 2008;9(6):554-60.

10. Deiss D, Kordonouri O, Hartmann R, Hopfenmüller W, Lüpke K, Danne T. Treatment with insulin glargine reduces asymptomatic hypoglycemia detected by continuous subcutaneous glucose monitoring in children and adolescents with type 1 diabetes. Pediatr Diabetes. 2007;8(3):157-62.

11. Robertson KJ, Schoenle E, Gucev Z, Mordhorst L, Gall MA, Ludvigsson J. Insulin detemir compared with NPH insulin in children and adolescents with type 1 diabetes. Diabet Med. 2007;24(1):27-34.

12. Herwig J, Scholl-Schilling G, Böhles H. Glycaemic control and hypoglycaemia in children, adolescents and young adults with 
unstable type 1 diabetes mellitus treated with insulin glargine or intermediate-acting insulin. J Pediatr Endocrinol Metab. 2007; 20(4):517-25.

13. Hermansen K, Madsbad S, Perrild H, Kristensen A, Axelsen M. Comparison of the soluble basal insulin analog insulin detemir with NPH insulin: a randomized open crossover trial in type 1 diabetic subjects on basal-bolus therapy. Diabetes Care. 2001;24(2):296-301.

14. - Hemkens LG, Grouven U, Bender R, Günster C, Gutschmidt S, Selke GW, Sawicki PT. Risk of malignancies in patients with diabetes treated with human insulin or insulin analogues: a cohort study. Diabetologia. 2009;52(9):1732-44. This article was one of the first to point out the possibly increased risk of cancer caused by insulin analogues. Even though other studies have shown different results, it is important to increase awareness of the risks associated with new drugs.

15. Sciacca L, Le Moli R, Vigneri R. Insulin analogs and cancer. Front Endocrinol (Lausanne). 2012;3:21.

16. Kalra S, Baruah MP. Niazi AK Degludec: a novel basal insulin. Recent Pat Endocr Metab Immune Drug Discov. 2012;6(1):18-23.

17. Nordwall M, Ludvigsson J. Use of an insulin pen with memory is not enough to give better glycaemic control. Pediatr Diabetes. 2011;12(Suppl 15).

18. Adolfsson P, Veijola R, Huot C, Hansen HD, Lademann JB, Phillip M. Safety and patient perception of an insulin pen with simple memory function for children and adolescents with type 1 diabetes-the REMIND study. Curr Med Res Opin. 2012;28(9): 1455-63.

19. - Olinder AL, Kernell A, Smide B. Missed bolus doses: devastating for metabolic control in CSII-treated adolescents with type 1 diabetes. Pediatr Diabetes. 2009;10(2):142-8. Missed insulin doses are common in treatment of T1D, not least in pump patients. This is a clinically very important finding!

20. Fuld K, Conrad B, Buckingham B, Wilson DM. Insulin pumps in young children. Diabetes Technol Ther. 2010;12(Suppl 1): S67-71.

21. Müller-Godeffroy E, Treichel S, German Working Group for Paediatric Pump Therapy. Investigation of quality of life and family burden issues during insulin pump therapy in children with type 1 diabetes mellitus-a large-scale multicentre pilot study. Diabetes Med. 2009;26(5):493-501.

22. • Yeh HC, Brown TT, Maruthur N, Ranasinghe P, Berger Z, Suh YD, Wilson LM, Haberl EB, Brick J, Bass EB, Golden SH. Comparative effectiveness and safety of methods of insulin delivery and glucose monitoring for diabetes mellitus: a systematic review and meta-analysis. Ann Intern Med. 2012;157(5):336-47. This metaanalysis underlines that an insulin pump is very useful, but not the solution

23. Pickup J. Insulin pumps. Int J Clin Pract Suppl. 2011;170:16-9.

24. Hanas R, Ludvigsson J. Hypoglycemia and ketoacidosis with insulin pump therapy in children and adolescents. Pediatr Diabetes. 2006;7(Suppl 4):32-8.

25. Tamborlane WV, Beck RW, Bode BW, Buckingham B, Chase HP, Clemons R, Fiallo-Scharer R, Fox LA, Gilliam LK, Hirsch IB, Huang ES, Kollman C, Kowalski AJ, Laffel L, Lawrence JM, Lee J, Mauras N, O'Grady M, Ruedy KJ, Tansey M, Tsalikian E, Weinzimer S, Wilson DM, Wolpert H, Wysocki T, Xing D. Continuous glucose monitoring and intensive treatment of type 1 diabetes. N Engl J Med. 2008;359:146476.

26. Choudhary P, Shin J, Wang Y, Evans ML, Hammond PJ, Kerr D, Shaw JA, Pickup JC, Amiel SA. Insulin pump therapy with automated insulin suspension in response to hypoglycemia: reduction in nocturnal hypoglycemia in those at greatest risk. Diabetes Care. 2011;34:2023-5.
27. • Danne T, Kordonouri O, Holder M, Haberland H, Golembowski S, Remus K, Blasig S, Wadien T, Zierow S, Hartmann R, Thomas A. Prevention of hypoglycemia by using low glucose suspend function in sensor-augmented pump therapy. Diabetes Technol Ther. 2011;13:1-6. A modern technique with improved pumps will most probably further improve both metabolic control and quality of life.

28. Holl RW, Swift PG, Mortensen HB, Lynggaard H, Hougaard P, Aanstoot HJ, Chiarelli F, Daneman D, Danne T, Dorchy H, Garandeau P, Greene S, Hoey HM, Kaprio EA, Kocova M, Martul P, Matsuura N, Robertson KJ, Schoenle EJ, Sovik O, Tsou RM, Vanelli M, Aman J. Insulin injection regimens and metabolic control in an international survey of adolescents with type 1 diabetes over 3 years: results from the Hvidore study group. Eur J Pediatr. 2003;162(1):22-9.

29. Ludvigsson J, Hanas R. Continuous subcutaneous glucose monitoring improved metabolic control in pediatric patients with type 1 diabetes: a controlled crossover study. Pediatrics. 2003;111(5 Pt 1):933-8.

30. Bergenstal RM, Tamborlane WV, Ahmann A, Buse JB, Dailey G, Davis SN, Joyce C, Peoples T, Perkins BA, Welsh JB, Willi SM, Wood MA, STAR 3 Study Group. Effectiveness of sensor-augmented insulin-pump therapy in type 1 diabetes. $\mathrm{N}$ Engl $\mathrm{J}$ Med. 2010;363(4):311-20.

31. Kamble S, Schulman KA, Reed SD. Cost-effectiveness of sensoraugmented pump therapy in adults with type 1 diabetes in the United States. Value Health. 2012;15(5):632-8.

32. Hovorka R. Closed-loop insulin delivery: from bench to clinical practice. Nat Rev Endocrinol. 2011;7:385-95.

33. Hovorka R, Allen JM, Elleri D, Chassin LJ, Harris J, Xing D, Kollman C, Hovorka T, Larsen AM, Nodale M, De PA, Wilinska ME, Acerini CL, Dunger DB. Manual closed-loop insulin delivery in children and adolescents with type 1 diabetes: a phase 2 randomised crossover trial. Lancet. 2010;375:743-51.

34. Särnblad S, Kroon M, Aman J. Metformin as additional therapy in adolescents with poorly controlled type 1 diabetes: randomised placebo-controlled trial with aspects on insulin sensitivity. Eur J Endocrinol. 2003;149(4):323-9.

35. Rr Enande, Gundevall C, Strömgren A, Chaplin J, Hanas R. Carbohydrate counting with a bolus calculator improves postprandial blood glucose levels in children and adolescents with type 1 diabetes using insulin pumps. Pediatr Diabetes. 2012; 13(7):545-51.

36. Błazik M, Pańkowska E. The effect of bolus and food calculator Diabetics on glucose variability in children with type 1 diabetes treated with insulin pump: the results of RCT. Pediatr Diabetes. 2012;13(7):534-9.

37. • Kordonouri O, Hartmann R, Remus K, Bläsig S, Sadeghian E, Danne T. Benefit of supplementary fat plus protein counting as compared with conventional carbohydrate counting for insulin bolus calculation in children with pump therapy. Pediatr Diabetes 2012;13(7):540-4. This article reveals that although carbohydrate counting may be good, it is not always sufficient to obtain good metabolic control and other components of food also have to be considered.

38. • Swift PG, Skinner TC, de Beaufort CE, Cameron FJ, Aman J, Aanstoot HJ, Castaño L, Chiarelli F, Daneman D, Danne T, Dorchy H, Hoey H, Kaprio EA, Kaufman F, Kocova M, Mortensen HB, Njølstad PR, Phillip M, Robertson KJ, Schoenle EJ, Urakami T, Vanelli M, Ackermann RW, Skovlund SE. Target setting in intensive insulin management is associated with metabolic control: the Hvidoere Childhood Diabetes Study Group Centre Differences Study 2005. Pediatr Diabetes. 2010;11(4):271-8. This is a very important article strongly suggesting that devices or the number of insulin injections alone cannot explain the degree of metabolic 
control, and perhaps as important is the approach and the goals of the diabetes team.

39. Ludvigsson J. Insulin, love and care. Horm Res. 1989;31:204-9.

40. Nordfeldt S, Hanberger L, Malm F. Ludvigsson J Development of a PC-based diabetes simulator in collaboration with teenagers with type 1 diabetes. Diabetes Technol Ther. 2007;9(1):17-25.

41. Ekberg J, Ericson L, Timpka T, Eriksson H, Nordfeldt S, Hanberger L, Ludvigsson J. Web 2.0 systems supporting childhood chronic disease management: design guidelines based on information behaviour and social learning theories. J Med Syst. 2010; 34(2):107-17.

42. Madsbad S, Alberti KG, Binder C, Burrin JM, Faber OK, Krarup $\mathrm{T}$, Regeur L. Role of residual insulin secretion in protecting against ketoacidosis in insulin-dependent diabetes. Br Med J. 1979;2:1257-9.

43. Steffes MW, Sibley S, Jackson M, Thomas W. Beta-cell function and the development of diabetes-related complications in the Diabetes Control and Complications Trial. Diabetes Care. 2003; 26:832-6.

44. Wahren J, Ekberg K, Jörnvall H. C-peptide is a bioactive peptide. Diabetologia. 2007;50(3):503-9.

45. Jun HS. Regeneration of pancreatic beta cells. Front Biosci. 2008;13:6170-82.

46. Ludvigsson J. C-peptide an adequate endpoint in type 1 diabetes. Diabetes Metab Res Rev. 2009;25(8):691-3.

47. Ludvigsson J, Heding L, Lieden G, Marner B, Lernmark A. Plasmapheresis in the initial treatment of insulin-dependent diabetes mellitus in children. Br Med J (Clin Res Ed). 1983;286:176-8.

48. Dupre J, Stiller CR, Gent M, et al. Clinical trials of cyclosporin in IDDM. Diabetes Care. 1988;11(Suppl 1):37-44.

49. Eisenbarth GS, Srikanta S, Jackson R, et al. Anti-thymocyte globulin and prednisone immunotherapy of recent onset type 1 diabetes mellitus. Diabetes Res. 1985;2:271-6.

50. Chase HP, Butler-Simon N, Garg S, McDuffie M, Hoops SL, $\mathrm{O}^{\prime}$ Brien D. A trial of nicotinamide in newly diagnosed patients with type 1 (insulin-dependent) diabetes mellitus. Diabetologia. 1990;33:444-6.

51. Pozzilli P, Visalli N, Signore A, et al. Double blind trial of nicotinamide in recent-onset IDDM (the IMDIAB III study). Diabetologia. 1995;38:848-52.

52. Coutant R, Landais P, Rosilio M, et al. Low dose linomide in type I juvenile diabetes of recent onset: a randomised placebo-controlled double blind trial. Diabetologia. 1998;41:1040-6.

53. Ludvigsson J, Samuelsson U, Johansson C, Stenhammar L. Treatment with antioxidants at onset of type 1 diabetes in children: a randomized, double-blind placebo-controlled study. Diabetes Metab Res Rev. 2001;17:131-6.

54. Ludvigsson J, Samuelsson U, Ernerudh J, Johansson C, Stenhammar L, Berlin G. Photopheresis at onset of type 1 diabetes: a randomised, double blind, placebo controlled trial. Arch Dis Child. 2001;85:149-54.

55. Herold KC, Gitelman SE, Masharani U, et al. A single course of antiCD3 monoclonal antibody hOKT3gamma1(Ala-Ala) results in improvement in C-peptide responses and clinical parameters for at least 2 years after onset of type 1 diabetes. Diabetes. 2005;54:1763-9.

56. Keymeulen B, Vandemeulebroucke E, Ziegler AG, et al. Insulin needs after CD3-antibody therapy in new-onset type 1 diabetes. N Engl J Med. 2005;352:2598-608.

57. Keymeulen B, Walter M, Mathieu C, Kaufman L, Gorus F, Hilbrands R, Vandemeulebroucke E, Van de Velde U, Crenier L, De Block C, Candon S, Waldmann H, Ziegler AG, Chatenoud L, Pipeleers D. Four-year metabolic outcome of a randomised controlled CD3-antibody trial in recent-onset type 1 diabetic patients depends on their age and baseline residual beta cell mass. Diabetologia. 2010;53(4):614-23.
58. Pescovitz MD, Greenbaum CJ, Krause-Steinrauf H, Becker DJ, Gitelman SE, Goland R, Gottlieb PA, Marks JB, McGee PF, Moran AM, Raskin P, Rodriguez H, Schatz DA, Wherrett D, Wilson DM, Lachin JM, Skyler JS. Type 1 Diabetes TrialNet Anti-CD20 Study Group Rituximab, B-lymphocyte depletion, and preservation of beta-cell function. $N$ Engl $\mathrm{J}$ Med. 2009;361(22):2143-52.

59. - Sherry N, Hagopian W, Ludvigsson J, Jain SM et al. Teplizumab for treatment of type 1 diabetes (Protégé study): 1-year results from a randomised, placebo-controlled trial. Lancet. 2011;378(9790):487-97. Even though this phase III trial failed, it showed that in certain subgroups this type of treatment is effcacious. With better selection of patients this type of treatment may be of value.

60. Raz I, Elias D, Avron A, Tamir M, Metzger M, Cohen IR. Betacell function in new-onset type 1 diabetes and immunomodulation with a heat-shock protein peptide (DiaPep277): a randomised, double-blind, phase II trial. Lancet. 2001;358(9295):1749-53.

61. Abulafia-Lapid R, Gillis D, Yosef O, Atlan H, Cohen IR. T cells and autoantibodies to human HSP70 in type 1 diabetes in children. J Autoimmun. 2003;20(4):313-21.

62. Lazar L, Ofan R, Weintrob N, et al. Heat-shock protein peptide DiaPep277 treatment in children with newly diagnosed type 1 diabetes: a randomised, double-blind phase II study. Diabetes Metab Res Rev. 2007;23(4):286-91.

63. Schloot NC, Meierhoff G, Lengyel C, Vándorfi G, Takács J, Pánczél P, Barkai L, Madácsy L, Oroszlán T, Kovács P, Sütö G, Battelino T, Hosszufalusi N, Jermendy G. Effect of heat shock protein peptide DiaPep277 on beta-cell function in paediatric and adult patients with recent-onset diabetes mellitus type 1: two prospective, randomized, double-blind phase II trials. Diabetes Metab Res Rev. 2007;23(4):276-85.

64. Pozzilli P, Guglielmi C, Maggi D, Carlone A, Buzzetti R, Manfrini S. Clinical update on the use of immuno modulators (antiCD3, GAD, Diapep277, anti-IL1) in type 1 diabetes. Curr Pharm Des. 2011;17(29):3224-8.

65. Baekkeskov S, Nielsen JH, Marner H, Bilde T, Ludvigsson J, Lernmark A. Autoantibodies in newly diagnosed diabetic children immunoprecipitate human pancreatic islet cell proteins. Nature. 1982;298:167-9.

66. Baekkeskov S, Aanstoot HJ, Christgau S, Reetz A, Solimena M, Cascalho M, Folli F, Richter-Olesen H, De Camilli P. Identification of the $64 \mathrm{~K}$ autoantigen in insulin-dependent diabetes as the GABA-synthesizing enzyme glutamic acid decarboxylase. Nature. 1990;347(6289):151-6.

67. Tian J, Clare-Salzler M, Herschenfeld A, et al. Modulating autoimmune responses to GAD inhibits disease progression and prolongs islet graft survival in diabetes-prone mice. Nat Med. 1996;2:1348-53.

68. Tisch R, Liblau RS, Yang XD, Liblau P, McDevitt HO. Induction of GAD65-specific regulatory $\mathrm{T}$ cells inhibits ongoing autoimmune diabetes in non-obese diabetic mice. Diabetes. 1998;47: 894-9.

69. Ludvigsson J, Faresjo M, Hjorth M, Axelsson S, Cheramy M, Pihl M, et al. GAD treatment and insulin secretion in recent-onset type 1 diabetes. N Engl J Med. 2008;359(18):1909-20.

70. Ludvigsson J, Hjorth M, Chéramy M, Axelsson S, et al. Extended evaluation of the safety and efficacy of GAD treatment of children and adolescents with recent-onset type 1 diabetes: a randomised controlled trial. Diabetologia. 2011;54(3):634-40.

71. - Ludvigsson J, Krisky D, Casas R, Battelino T, et al. GAD65 antigen therapy in recently diagnosed type 1 diabetes mellitus. N Engl J Med. 2012;366(5):433-42. This phase III trial failed, but shows that autoantigen treatment may be a useful concept, with an effect in certain subgroups of patients. As the treatment is 
extremely simple and without treatment-related adverse events, it should be developed further.

72. Wherrett DK, Bundy B, Becker DJ, et al. Antigen-based therapy with glutamic acid decarboxylase (GAD) vaccine in patients with recent-onset type 1 diabetes: a randomised double-blind trial. Lancet. 2011;378(9788):319-27.

73. Barton FB, Rickels MR, Alejandro R, Hering BJ, Wease S, Naziruddin B, Oberholzer J, Odorico JS, Garfinkel MR, Levy M, Pattou F, Berney T, Secchi A, Messinger S, Senior PA, Maffi P, Posselt A, Stock PG, Kaufman DB, Luo X, Kandeel F, Cagliero E, Turgeon NA, Witkowski P, Naji A, O'Connell PJ, Greenbaum C, Kudva YC, Brayman KL, Aull MJ, Larsen C, Kay TW, Fernandez LA, Vantyghem MC, Bellin M, Shapiro AM. Improvement in outcomes of clinical islet transplantation: 1999-2010. Diabetes Care. 2012;35(7):1436-45.

74. Qi Z, Yamamoto C, Imori N, Kinukawa A, Yang KC, Yanai G, Ikenoue E, Shen Y, Shirouzu Y, Hiura A, Inoue K. Sumi S Immunoisolation effect of polyvinyl alcohol (PVA) macroencapsulated islets in type 1 diabetes therapy. Cell Transplant. 2012; 21(2-3):525-34.

75. Domínguez-Bendala J, Lanzoni G, Inverardi L, Ricordi C. Concise review: mesenchymal stem cells for diabetes. Stem Cells Transl Med. 2012;1(1):59-63.

76. Rother KI, Spain LM, Wesley RA, Digon BJ 3rd, Baron A, Chen K, Nelson P, Dosch HM, Palmer JP, Brooks-Worrell B, Ring M,
Harlan DM. Effects of exenatide alone and in combination with daclizumab on beta-cell function in long-standing type 1 diabetes. Diabetes Care. 2009;32(12):2251-7.

77. Dungan KM, Buse JB, Ratner RE. Effects of therapy in type 1 and type 2 diabetes mellitus with a peptide derived from islet neogenesis associated protein (INGAP). Diabetes Metab Res Rev. 2009;25(6):558-65.

78. Hyppönen E, Läärä E, Reunanen A, Järvelin MR, Virtanen SM. Intake of vitamin $\mathrm{D}$ and risk of type 1 diabetes; a birth-cohort study. Lancet. 2001;358:1500-3.

79. Zipitis CS, Akobeng AK. Vitamin D supplementation in early childhood and risk of type 1 diabetes: a systematic review and meta-analysis. Arch Dis Child. 2008;93:512-7.

80. Walter M, Kaupper T, Adler K, Foersch J, Bonifacio E, Ziegler A-G. No effect of the 1 $\alpha, 25$-dihydroxyvitamin D3 on $\beta$-cell residual function and insulin requirement in adults with newonset type 1 diabetes. Diabetes Care. 2010;33(7):1443-8.

81. Bizzarri C, Pitocco D, Napoli N, Di Stasio E, Maggi D, Manfrini S, Suraci C, Cavallo MG, Cappa M, Ghirlanda G, Pozzilli P, IMDIAB Group. No protective effect of calcitriol on $\beta$-cell function in recent-onset type 1 diabetes. The IMDIAB XIII trial. Diabetes Care. 2010;33(9):1962-3.

82. Pickersgill LM, Mandrup-Poulsen TR. The anti-interleukin-1 in type 1 diabetes action trial-background and rationale. Diabetes Metab Res Rev. 2009;25(4):321-4. 